Jurnal Konstruksi Hukum | ISSN: 2746-5055

Vol. 2, No. 1, Januari $2021 \mathrm{Hal}$. 5-9 | Tersedia online di

https://www.ejournal.warmadewa.ac.id/index.php/jukonhum

DOI: https://10.22225/jkh.2.1.2958.5-9

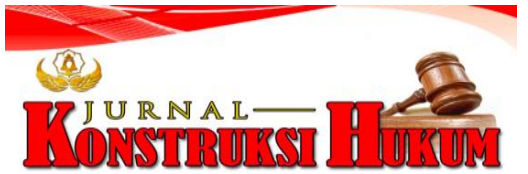

\title{
TINJAUAN YURIDIS TERHADAP DAMPAK EKSPLOITASI PERDAGANGAN ANAK DENGAN MODUS PERKAWINAN
}

\author{
A.A. Ngurah Bagus Arya Bhaskara, I Nyoman Gede Sugiartha, Diah Gayatri Sudibya \\ Fakultas Hukum Universitas Warmadewa, Denpasar-Bali, Indonesia
}

\begin{abstract}
Abstrak
Penyebab utama kejahatan seksual yaitu faktor ekonomi dan kurangnya pendidikan formal, sehingga memicu terjadinya kejahatan eksploitasi seksual perdagangan anak dengan modus perkawinan yang biasa mengincar korbannya sebagian besar anak-anak atau perempuan. Penelitian ini bertujuan untuk mengetahui dampak dari eksploitasi perdagangan anak dengan modus perkawinan dilihat dari aspek Undang-Undang Tindak Pidana Perdagangan Orang dan mengetahui sanksi terhadap pelaku tindak pidana perdagangan anak dengan modus perkawinan yang terjadi di Indonesia. Penilitian ini menggunakan metode hukum normatif. Hasil analisis menunjukan bahwa dampak yang dapat ditimbulkan terhadap korban anak-anak maupun perempuan yaitu dampak terhadap fisik maupun psikologis, emosional, spiritual, serta terganggu kesehatannya. Kemudian, sanksi terhadap pelaku diatur dalam Pasal 297 yang terdapat dalam KUHP dan dalam Undang-Undang Nomor 21 Tahun 2007 Tentang Pemberantasan Tindak Pidana Perdagangan Orang, Undang-Undang Nomor 23 Tahun 2002 Tetang Perlindungan Anak dan juga Undang-Undang Nomor 13 Tentang Ketenagakerjaan.
\end{abstract}

Kata Kunci: Dampak eksploitasi anak, Modus perkawinan, Perdagangan orang

\begin{abstract}
The main causes of sexual crimes are economic factors and a lack of formal education, which triggers the crime of sexual exploitation of child trafficking with the marriage mode, which usually targets mostly children or women. This study aims to determine the impact of the exploitation of child trafficking by means of marriage as seen from the aspects of the Law on Trafficking in Persons and to find out the sanctions against perpetrators of child trafficking with the mode of marriage that occur in Indonesia. This research uses the normative legal method. The results of the analysis show that the impact that can be had on children and women victims is the impact on physical and psychological, emotional, spiritual, and disturbed health. Then, sanctions against perpetrators are regulated in Article 297 contained in the Criminal Code and in Law Number 21 of 2007 concerning the Eradication of the Crime of Trafficking in Persons, Law Number 23 of 2002 Concerning Child Protection and also Law Number 13 concerning Manpower.
\end{abstract}

Keywords: Impact of child exploitation, Mode of marriage, Human trafficking

\section{PENDAHULUAN}

Belakangan ini kasus perdagangan orang di Indonesia semakin marak terjadi. Namun dalam hal ini yang paling menonjol terjadi yaitu perdagangan anak dan perempuan dalam industri seksual yang sudah mulai menjadi perhatian serius dalam masyarakat. Oleh karenanya, perdagangan orang sudah bukan merupakan kejahatan baru dalam lingkup masyarakat, bahkan kejahatan ini sangat sulit dijangkau oleh media-media karena kegiatannya masih dalam skala yang kecil dan biasanya sangat terorganisir sehingga sulit diusut keberadaannya. Di dunia bahkan terdapat negara yang paling besar terjadi kasus kejahatan perdagangan orang dan terdapat fakta bahwa Indonesia menjadi salah satu negara yang paling tinggi angka kasus kejahatan perdagangan orang didunia.

Biasanya dalam kasus ini yang kerap menjadi korban dalam kasus ini yaitu anak-anak dan perempuan yang berlatarbelakang perekonomian yang kurang serta tidaknya mendapat pendidikan yang cukup dalam mengenyam bangku sekolah sehingga menjadi pihak yang rawan dimanfaatkan oleh pelaku kejahatan perdagangan orang dan juga eksploitasi tersebut. Berikut ini beberapa penelitian terdahulu yang membahas tentang exploitasi manusia dan cara untuk memulihkan mental korban perdagangan manusia, seperti Aloyo \& Cusumano (2018); Azaola (2006); da Silva \& Sathiyaseelan (2019); Kelly \& Regan (2000); Powell, Dickins, \& Stoklosa (2017); Thompson, Tupe, Wadley, \& Flanagan (2019). Dalam kasus perdagangan anak terdapat berbagai macam modusyang semakin tahun semakin maju, cotohnya saat ini banyak terjadi tindak pidana perdagangan orang secara online guna 
menarik pengguna sosial media, lalu ada dengan menggunakan modus perkawinan yang selanjutnya dieksploitasi baik secara seksual maupun eksploitasi ekonomi, serta banyak modus lainnya. Dalam modus perkawinan ini dilakukan dengan cara memaksa anak kawin dengan seseorang yang biasanya seseorang yang jauh lebih tua dari anak, guna untuk mendapatkan sesuatu dari calon menantu serta kepentingan mendapatkan penghidupan yang lebih layak sehingga dibalik adanya pemberian tesebut maka terdapat tindak pidana yang dilakukan oleh orang tua anak terhadap anaknya dan adanya pelanggaran hak-hak terhadap anak.

Keterdesakan masalah ekonomi merupakan penyebab utama banyaknya perempuan dan anak terjerumus dalam lingkaran perdagangan orang. Masalah ekonomi menjadikan manusia mencari jalan keluar yang mudah dan cepat untuk memenuhi setiap kebutuhannya, ketersediaan lapangan pekerjaan tidak lagi sesuai dengan laju pertumbuhan penduduk dan pertumbuhan perekonomian (Hatta, 2012:2).

Melalui penelitian ini, peneliti ingin membahas dampak dari eksploitasi perdagangan anak dengan modus perkawinan jika dilihat dari aspek Undang-Undang Tindak Pidana Perdagangan Orang dan bagaimanakah sanksi terhadap pelaku tindak pidana perdagangan anak dengan modus perkawinan yang terjadi di Indonesia?

\section{METODE PENELITIAN}

Penelitian ini menggunakan metode penelitian hukum normatif dengan melihat peristiwa atau perbuatan hukum yang ada di dalam masyarakat dan melihat peraturan-peraturan hukum serta pendekatan yang digunakan yaitu dengan mempergunakan pendekatan perundang-undangan dan pendekatan konsep Sumber data dalam pengkajian permasalahan hukum tersebut dengan sumber bahan hukum. Bahan hukum yang digunakan adalah bahan hukum primer, bahan hukum sekunder, dan bahan hukum tersier.

Metode yang digunakan dalam pengumpulan bahan hukum adalah dengan cara mengumpulkan, mengkaji, dan mengolah secara sistematis bahan-bahan kepustakaan dan dengan menganalisis peraturan perundang- undangan.Selanjutnya diolah dan dianalisis secara sistematis dengan menggunakan metode argumentasi hukum berdasarkan logika hukum deduktif dan induktif. Hasil analisis akan dipaparkan secara deskriptif, sehingga diperoleh gambaran yang menyeluruh tentang permasalahan yang diteliti.

\section{HASIL DAN PEMBAHASAN}

Terjadinya tindak pidana peradagangan anak tersebut disebabkan oleh faktor- faktor yang timbul dari pelaku maupun korban yang bersangkutan. Namun apapun alasannya, perkawinan dibawah umur jika ditinjau dari berbagai aspek sangatlah merugikan kepentingan anak dan serta sangat membahayakan kesehatan anak akibat dampak perkawinan dini atau perkawinan dibawah umur itu sendiri.

Dalam Undang-Undang Dasar Negara Republuk Indonesia 1945 menyebutkan seluruh warga Negara berhak memperoleh pendidikan serta keadilan yang sama dimata hukum. Apabila Negara tidak dapat memberikan pengakuan serta pertanggungan yang layak atas Hak Asasi Manusia (HAM) warga negaranya, maka Negara tersebut bukan Negara hukum. Menurut, Prakoso (2016:13-14), dasardasar hukum perlindungan anak diantaranya:

a. Dasar filosofis yaitu pancasila sebagaimana dimaksud sebagai pedoman dimana nilai-nilai yang tercantum dalam pancasila itu sendiri digunakan sebagai dasar dalam bermasyarakat, berbangsa dan bernegara atau pula digunakan sebagai dasar filosofi dalam perlindungan dari hak anak itu sendiri.

b. Dasar etis yaitu dimana dalam pelaksanaanya suatu perlindungan terhadap anak haruslah sesuai sebagaimana dengan kode etik yang berkaitan, guna pencegahan terhadap perilaku sewenang-wenang atau menyimpang dalam kewenangannya.

c. Dasar yuridis yaitu terhadap pelaksanaannya suatu perlindungan terhadap anak haruslah berlandaskan pada hukum serta peraturan yang berwenang dan berlaku, dikarenakan dalam hal ini penerapan harus secara integrasi dimana perlu adanya kebijakan-kebijakan yang lebih tegas mengatur mengenai sanksi terhadap pelanggar tindak pidana terhadap anak itu sendiri.

Oleh karena itu, setiap anak dan korban dari perdagangan anak berhak mendapatkan perlindungan dan pendampingan hukum. Anak yang diperdagangkan merupakan korban, sehingga mereka tidak boleh diperlakukan sebagai pelanggar maupun diancam dengan sanksi kriminal atas tindakan pelanggaran yang terkait dengan situasi mereka sebagi anak yang di perdagangkan. Mengenai perlindungan 
terhadap korban tidak hanya perlindungan yang meliputi fisik saja melainkan juga terhadap psikisnya (Sunarsono, 2012:7).

Dalam berbagai aspek kehidupan sangat diperlukan peran aktif masyarakat dalam hal penyelenggaraan keamanan negara guna membantu penegakan hukum terhadap tingginya kasus eksploitasi anak, sehingga aparat hukum dalam menegakan hukum akan lebih efektif. Upaya perlindungan terhdap korban itu sendiri masih bersifat kompleks dengan begitu perlu peran aktif masyarakat dalam menegakannya. Sementara, yang terjadi selama ini penanganan masalah hanya berfokus pada masalah yang sudah terjadi serta penyelesaian terhadap kasus, sedangkan dalam proses pencegahannya dan perlidungan terhadap hak anak sendiri masih sangat kurang. Ini harus diperhatikan! Sebagaimana terdapat di dalam KUHP, saat ini, tidak adanya ganti rugi sebagaimana baik pidana pokok maupun tambahan (Arief, 2010:56-57).

Tindak pidana khususnya eksploitasi anak itersebut merupakan sebuah tindakan ataupun perbuatan yang dapat dikategorikan dalam perbuatan yang melanggar suatu hak asasi manusia anak itu sendiri. Maka dari itu mengenai pengertian dari tindak eksploitasi anak itu sendiri adalah segala bentuk penyalahgunaan, memanfaatkan atau mendayagunakan anak dengan merampas hak-hak anak itu sendiri guna mendapatkan keuntungan pribadi yang merupakan perbuatan-perbuatan yang tidak terpuji yang dapat melanggar hak asasi manusia anak itu sendiri. Oleh karena itu, tindakan eksploitasi terhadap anak sangat menonjolkan sifat yang intoleran maupun perbuatan yang tidak pantaskepada anak yang dilakukan suatu oknum yang memaksakananak tidak sesuai kehendaknya dalam melakukan sesuatu hal guna menunjang kebutuhan ekonominya yang sama sekali tidak memperhatikan ataupun memperdulikan perlindungan terhadap anak itu sendiri yang meliputi psikis atau mental, fisik serta keadaan sosialnya.

Keberadaan perdagaangan anak dan perempuan telah memberikan ancaman tersendiri terhadap keberadaan keamanan orang di Indonesia. Peningkatan angka kasus perdagangan manusia, khususnya terhadap anak-anak dan perempuan, menyebabkan timbulnya pertanyaan mengenai keselamatan anakanak dan perempuan di Indonesia. Dikarenakan semakin meningkatnya jumlah perdagangan manusia membuktikan bahwa kepedulian akankeselamatan serta pada nilai-nilai kemanusiaan yang dimiliki masyarakat di Indonesia masih sangat kurang.

Terdapat berbagai dampak negatif yang di alami korban akibatdari hasil tindak eksploitasi anak itu sendiri tidak hanya berdampak pada fisik karena mengalami kekerasan seperti cacat, luka, maupun kekerasan seksual yang berdampak pada organ intim dari perempuan dan anak-anak itu sendiri tetapi juga dapat berdampak pada psikologis yang berpengaruh kepada mental mereka dimana itu merupakan luka permanen yang akan sulit mreka lupakan sehingga menimbulkan trauma pada mereka. Kemudian tentu saja akan timbul suatu pandangan negatif dalam lingkungan masyarakat atau lingkungan tempat tinggal mereka dimana rasa percaya diri mereka akan hilang dan bahkan mereka dikucilkan oleh masyarakat sehingga menimbulkan stres yang efeknya bisa membahayakan nyawa mereka karena rentan melakukan bunuh diri akibat stres yang mereka alami.

Dalam hal perdagangan anak yang dilakukan dengan modus perkawinan ini masyarakat terutama orangtua haruslah memperhatikan mengenai syarat-syarat sahnya suatu perkawinan serta batasan usia agar suatu perkawinan berjalan sesuai dengan hukum yang mengatur di Indonesia. Dimana dalam hal ini kurangnya pemahaman masyarakat mengenai syarat sahnya perkawinan di Indonesia, sehingga terjadinya perkawinan dibawah umur masih marak terjadi dan sudah menjadi hal yang wajar di Indonesia. Salah satu faktornya dimana masih adanya perkawian dibawah umur karena berlandaskan tradisi yang sudah turun-menurun ada dalam suatu komunitas guna pengamalan ajaran agama mereka. Selain itu ada faktor penyebab perkawinan dibawah umur seperti persoalan ekonomi, rendahnya mengenyam bangkupendidikan serta kurangnya pemahaman budaya dan nilai-nilai agama tertentu, dan juga karena faktor hamil diluar nikah.

Pengertian perdagangan terhadap anak dan perempuan dapat dikatakan sebagai perbuatan yang dalam hal ini disertai dengan proses-proses perekrutan serta pemindahan terhadap orang tersebut, yang bertujuan memperkerjakan secara tidak layak atau termasuk dalam tindakan eksploitasi seks komersial dengan ancaman terhadap kekerasan, penipuan, serta dengan modus dijerat hutang.

Sejalan dengan cepatnya kemajuan suatu ilmu pengetahuan serta teknologi itu sendiri maka semakin pesat pulapesatnya perkembangan terhadap kejahatan diseluruh dunia ini. Jika dilihat dari segi kapasitas dan jumlah maka perlunya pembahasan serta pengamatan terhadap suatu permasalahanpermasalahan yang terjadi karena tanpa adanya mempelajari penyebab suatu kejahatan itu sendiri 
maka sangat sukar mengetahui alasan hal tersebut terjadi terutama guna menemukan suatu tindakan yang tepat untuk menangani pelaku kejahatan itu sendiri (Ali, 2011:40).

Problematika kasus dengan maksud mengeksploitasi seksual terhadap anak dan perempuan secara komersil terus meningkat. Dimana anak-anak diperjual belikan atau diperdagangkan untuk melayani hubungan badan yang dapat menimbulkan trauma yang cukup mendalam pada anak. Oleh karena terus bertambahnya kasus diperdagangkannya anak untuk pekerja seks komersial tak dapat dipungkiri karena kurangnya upaya penanggulangannya karena tidak adanyapemberian sanksi (hukuman) yang tegas bagi para pelakunya.

Selain itu, adanya faktor intern dan ekstern dimana juga menyebabkan maraknya terjadi kasus perdagangan anak dan perempuan itu sendiri dimana faktor intern yaitu diantaranya berasal dari individu itu sendiri, kemudian faktor kebutuhan ekonomi yang dialaminya, faktor keluarga, dan serta faktor pendidikan yang kurang memadai. Kemudian pula faktor ekstern penyebab terjadinya perdagangan perempuan dan anak yaitu faktor lingkunan sekitarnya dan faktor lemahnya penegakan hukum terhadap kasus ini.

Dalam hal ini, mengenai klasifikasi bentuk-bentuk dari perdagangan anak- anak dan perempuan yang biasa marak terjadi di Indonesia antara lain pelacuran (prostitusi), pornografi anak, perdagangan anak, pariwisata seks anak, dan serta perkawinan anak. Oleh karena itu, dalam hal perlindungan terhadap anak dari berbagai aspek upaya dalam memajukan bangsasehingga pentingnya melindungi anak sejak dini bahkan hingga anak dewasa, karena anak merupakan amanah sekaligus karunia yang diberikan dari Tuhan Yang Maha Esa. Anak diperhatikan dalam segi aspek sebagai warga negara, yaitu sebagai generasi penerus bangsa Indonesia berhak memperoleh perlindungan atas hukum dari tindak kekerasan dan diskriminasi serta memperoleh hak untuk kebebasannya. Hak asasi anak juga merupakan bagian dari hak asasi manusia yang dimana nilai-nilai yang terkandung haruslah dijunjung tinggi keberadaannya.

Mengenai sanksi pidana terhadap pelaku eksploitasi seksual anak terdapat dua pengaturan mengenai penerapan sanksi pidana eksploitasi seksual terhadap perdagangan anak serta perempuan, yaitu sanksi pidana yang diatur atau terdapat didalam Kitab Undang-Undang Hukum Pidana maupun Undang-Undang. Dalam Kitab Undang-Undang Hukum Pidana yang ada di Indonesia mengenai penegakan sanksi dalam KUHP yang biasa kita sebut dengan KUHP. Dimana sanksi pidana perdagangan anak dalam KUHP terdapat sistematika dalam hal tindak eksploitasi seksual terhdap anakyang sebagaimana dimaksud dalam Pasal 297, yaitu membahas mengenai hukuman yang dibebankan terhadap pelaku tindak pidana perdagangan anak dan perempuan yang masih dibawah umur, dikenakan hukuman pidana penjara selama 6 (enam) tahun. Maka dapat ditarik kesimpulan dalam pasal ini mengatakan bahwa perdagangan terhadap anak maupun perempuan itu sendiri merupakan salah satu perbuatan melanggar hukum pidana.

Kemudian membahas mengenai sanksi pidana yang diatur didalam Undang- Undang,tercantum sebagian pengaturanyang mengatur mengenai penerapan terhadap sanksi pidana terhadap pelaku, diantaranya Undang-Undang Republik Indonesia Nomor 21 Tahun 2007 yang membahas tentang Pemberantasan Tindak Pidana Perdagangan Orang yang termuat didalam pasal 2 ayat (1), menyatakan hukuman terhadap pelaku yang melakukan tindakan ataupun perbuatan yang dalam hal ini disertai dengan penculikan, penyekapan dalam proses-proses perekrutan serta pemindahan terhadap orang tersebut, yang bertujuan memperkerjakan secara tidak layak atau termasuk dalam tindakan eksploitasi seks komersial dengan ancaman terhadap kekerasan, serta penipuan dengan tanpa persetujuan orang tersebut akan dikenakan pidana penjara minimal 3 (tiga) tahun dan pidana penjara maksimalnya 15 (lima belas) tahun disertai dengan denda minimal Rp.120.000.000 dan denda maksimal Rp.600.000.000.

Didalam Undang-Undang Republik Indonesia Nomor 23 Tahun 2002 yang membahas tentang Perlindungan Anak Pasal 83. Dimana pada pasal 83 mengatur mengenai jual beli anak,yaitu menyebutkan sanksi terhadap oknum atau orang yang memperdagangkan anak atau menjual anak dikenakan hukuman pidana penjara minimal 3 (tiga) tahun dan pidana penjara maksimalnya 15 (lima belas) tahun disertai dengan denda minimal Rp. 60.000.000 dan denda maksimalnya Rp.300.000.000. Selain itu, di dalam Undang-Undang Republik Indonesia No. 13 Tahun 2003 tentang Ketenagakerjaan Pasal 183, menyatakan hukuman bagi pelaku yang melanggar hak-hak pekeja maupun penyalahgunaan wewenang terhadap moral disertai dengan kekerasan yang diakukan terhadap anak 
akan dikenakan hukuman pidana penjara minimal 2 (dua) tahun dan pidana penjara maksimal 5 (lima) tahun dengan disertai denda minimal Rp. 200.000.000 dan maksimal dendanya yaitu Rp. 500.000.000.

\section{SIMPULAN}

Melalui hasil dari pembahasan yang diuraikan diatas, maka diperoleh kesimpulan bahwa dampak dari terjadinya eksploitasi dalam perdagangan anak dengan modus perkawinan tersebut dapat menimbulkan dampak negatif bagi korban ataupun anak itu sendiri, diantaranya baik berdampak pada fisik maupun dampak psikologisnya, tetapi juga berdampak pada emosional, serta dampak spiritual yang dapat mengganggu anak seumur hidupnya dan bahkan dapat mengancam jiwanya. Berikutnya, anak dapat pula terganggu kesehatannya karena anak dapat terjangkit virus atau penyakit. Korban juga akan mengalami kerusakan organ intim atau reproduksinya akibat dari hubungan seksual pada usia dini, anak akan hilang rasa kepercayaan dirinya akibat timbulnya stigma sosial atau pandangan yang buruk terhadap dirinya di masyarakat sekitarnya sehingga timbulnya rasa malu dari korban atau anak itu sendiri. Selain itu juga berdampak lain pada pendidikannya, karena anak tidak dapat melanjutkan pendidikannya dikarenakan putus sekolah.

Kemudian, sanksi kepada pelaku tindak pidana perdagangan anak dengan modus perkawinan yang terjadi di Indonesia dijerat dengan Pasal 297 yang terdapat dalam KUHP dan dalam UndangUndang Nomor 21 Tahun 2007 Tentang Pemberantasan Tindak Pidana Perdagangan Orang dikenakan pidana penjara minimal 3 (tiga) tahun dan pidana penjara maksimalnya 15 (lima belas) tahun disertai dengan denda minimal Rp.120.000.000 dan denda maksimal Rp.600.000.000, Undang-Undang Nomor 23 Tahun 2002 Tetang Perlindungan Anak diberi hukuman pidana penjara minimal 3 (tiga) tahun dan pidana penjara maksimalnya 15 (lima belas) tahun disertai dengan denda minimal Rp. 60.000.000 dan denda maksimalnya Rp. 300.000.000, dan juga Undang-Undang Nomor 13 Tentang Ketenagakerjaan dikenakan hukuman pidana penjara minimal 2 (dua) tahun dan pidana penjara maksimal 5(lima) tahun dengan disertai denda minimal Rp. 200.000.000 dan maksimal dendanya yaitu Rp. 500.000.000.

Kendatipun demikian, diharapkan kepada orangtua untuk lebih mengawasi anak-anaknya serta memahami dampak yang ditimbulkan dari eksploitasi seksual anak, yang sangat membahayakan anak sehingga dapat meminimalisir terjadinya perdagangan anak dengan modus pernikahan. Diharapkan kepada pemerintah dan DPR (Lembaga Pembentuk UU) lebih memperberat sanksi pidana terhadap pelaku eksploitasi anak dengan modus perkawinan tersebut sehingga penegakan dapat dilaksanakan dengan baik sesuai dengan Undang-Undang yang ada, dan tidak hanya sebatas formalitas belaka.

\section{DAFTAR PUSTAKA}

Ali, M. (2011). Dasar-Dasar Hukum Pidana. Jakarta: Sinar Grafika.

Aloyo, E., \& Cusumano, E. (2018). Morally Evaluating Human Smuggling: the Case of Migration to Europe. Critical Review of International Social and Political Philosophy, 00(00), 1-24.

Arief, B. N. (2010). Masalah Penegakan Hukum dan Kebijakan Hukum Pidana dalam Penanggulangan Kejahatan. Jakarta: Kencana Prenada.

Azaola, E. (2006). The Sexual Exploitation of Children in Mexico. Police Practice and Research, 7(2), 97-110.

da Silva, I. M., \& Sathiyaseelan, A. (2019). Emotional Needs of Women Post-rescue from Sex Trafficking in India. Cogent Psychology, 6(1), 1-12.

Hatta, M. (2012). Tindak Pidana Perdagangan Orang dalam Teori dan Praktek. Yogyakarta: Liberty.

Kelly, L., \& Regan, L. (2000). Sexual Exploitation of Children in Europe: Child Pornography. Journal of Sexual Aggression, 6(1-2), 6-28.

Powell, C., Dickins, K., \& Stoklosa, H. (2017). Training US Health Care Professionals on Human Trafficking: Where Do We Go from Here? Medical Education Online, 22(1), 1-12.

Prakoso, A. (2016). Hukum Perlindungan Anak. Yogyakarta: LaksBang PRESSindo.

Sunarsono, S. (2012). Viktimologi dalam Sistem Peradilan Pidana. Jakarta: Sinar Grafika.

Thompson, L., Tupe, L., Wadley, D., \& Flanagan, K. (2019). Mobilizing Cultural Supports against the Commercial Sexual Exploitation of (female) Children (CSEC) in Solomon Islands Community Development. Community Development, 50(3), 1-17. 